\title{
Illegal Migration and Strategic Challenges: A Case Study of Undocumented Migration from Bangladesh to India
}

\author{
M Mayilvaganan*
}

\begin{abstract}
Generally people move either legally or illegally due to socioeconomic and environmental reasons like poverty, unemployment and climate change or in search of better opportunities like for work and education, apart from for the reasons of reunification with family members, or the fear of persecution by other ethnic and political groups. In India as per the census 2001 data the total number of migrants is 314 million. Out of these, migrants from Bangladesh are around 10-20 million, who are mostly undocumented and crossed the border illegally. Though the migration brings in positive contribution, but the illegal ones pose serious challenges to the receiving State. The paper focuses on illegal immigration from Bangladesh to India and its implications.
\end{abstract}

Keywords: Illegal Migration, Undocumented Migration, Bangladesh, Northeast India and Assam

\section{Introduction}

The Bangladeshi immigration in India is one of the persistent problems that have emerged time and again as a major national security issue in terms of inland security and also to a large extent a demographic problem. Even if the crisis has loomed over for

\footnotetext{
* National Institute of Advanced Studies, Bangalore, India; mumayil@yahoo.com
} 
decades, India has not been very effective in curbing the menace of illegal entries or migration into the Indian Territory. Apparently, the successive Indian governments in the past have overlooked the issue and the entire issue was viewed from the point of political dividends. But with local conflicts in Northeast linking 'illegal' Bangladeshi migrants, particularly in Assam that paved way for public outrage, in turn, dragged the issue to the apex court, Supreme Court and the issue eventually acquired international dimension. On the other hand, the poor rural Bangladeshis who face poverty and whose existence is in question, don't bother the border and the implications of crossing over to another sovereign country as immigration is the only known safe option for their problem. However, Bangladeshi immigration to India's northeastern states has created significant implications, particularly in the realm of demography, socio-political environment, and economy.

\subsection{Migration}

Migration refers to the movement of people from one place to another in search of better living conditions. International Organisation for Migration defines migration as 'the movement of a person or a group of persons, either across an international border or within a State. It is a population movement, encompassing any kind of movement of people, whatever its length, composition and causes; it includes migration of refugees, displaced persons, economic migrants, and persons moving for other purposes, including family reunification (Key Migration Terms, n.d.).'

Illegal immigrationi can be defined as the migration of people across national borders or residing in a country that violates the destination country's national law (civil or criminal law). Generally, when a person (potential immigrant) believes that there are better chances or benefits than staying in his or her country of habitat, he or she takes the risk of crossing illegally to another country. 
It is estimated that the number of international migrants is 214 million according to the International Organization for Migration, 2010, in which, 'irregular' or 'illegal' migrants are estimated about 30-50 million worldwide. Further, it has been estimated that at the end of the 20th century some 150 million people were living outside the country of their birth and it is predicted it will increase to about 405 million by 2050 (World Migration Report, 2010).

As per the Indian Census 2001, the data on migration in India shows that the total number of migrants has been 314 million. Out of these, Bangladeshi migrants who form around 10-20 million are considered to be the largest one from outside country category. Whereas the World Migration Report 2010 reports state that 17 million undocumented Bangladeshi are in India (Ibid). Other smaller numbers of migrants are (a few thousand) are from Sri Lanka, Myanmar, Pakistan, Afghanistan, Africa, and Tibet.

Clearly, migration is a global phenomenon that is driven by various factors such as socio-economic disparities, environmental and climate change issues, and domestic political dynamics, etc. which plays an important part in the movement of people globally. Mainly, people leave their habitation in search of opportunities for work, education, reunification with family members, or for other reasons apart from the fear of persecution by other ethnic and political groups. People move sometime voluntarily and in other cases, forced by certain factors. Interestingly, in the case of Bangladesh, people don't essentially move to far off places; they prefer to move to areas close to them which are accustomed to their geography and cultures. In some cases, after the initial crossing over to geographical neighbourhood, they tend to migrate to other far off places.

Potential migrants are motivated by the "push" and "pull" factors. The 'push' factors are generally the conditions that exist in his place of residence, whereas 'pull' factors are destination areas that are perceived as the best place for earning, education and a decent livelihood. The presence of a network of their own people or predecessors from their neighbourhood too acts as a catalyst. For the people of Bangladesh, usually India has been a preferred 
destination, particularly; West Bengal and Assam due to the linguistic, cultural and religious linkages.

Migration contributes to both positive as well as negative impacts on the receiving/host country. One can positively contribute to the economic growth at the same time it can create demographic and socio-political problems. The unrelenting flow of illegal or undocumented migration to India has posed a serious threat to national security and has challenged the social harmony and economic well-being of the respective societies. The political and communal tensions in Assam and tensions in the Indo-Bangladesh border are a few cases in point. Besides, today there is a cause of concern with the reported linkage of the illegal migrants and the extremist group that has profound implications towards the regional security and bilateral relations among the states.

\section{2. Methods Adopted}

The three general methods that a potential migrant adopts to cross the border are:

a) Border crossing - crossing the border at the vulnerable porous border spots in the dark of the night. Sometimes, even in the day time, migrants venture into other parts of the country by bribing the border guards in the name of going to nearby places for shopping or purchase of local items.

b) Overstaying beyond the visa period - some migrants come through legal channels with a valid visa, however, by the end of the visa period instead of returning back to their country of origin, they overstay with concealed identity in some other parts of India.

c) Sham marriages - the third method adopted by some migrants is through a marriage alliance with an Indian girl or boy to settle permanently in the country.

Notably, brokers or dalals play an important role in the crossing of the border. The dalals are either those who return from India or the ones who have developed nexus with the local officials and people 
and security officials through some economic incentives. Some reports suggest that migrants pay about BDT 1000 to BDT 3000 to the dalals for aiding in crossing the border whereas others go on their own to the designated porous border points by bribing.

\subsection{Pattern of Migration}

For one set of migrants, India is the destination while for some it is a transit. Among the migrants, most of them are unskilled labourers (labour work), some work as domestic workers after crossing the border, while few come as agricultural workers and honey collectors. Another chunk of migrants ends up as construction workers/painters, workers in garment industries and as machine operators. The networks of their predecessors and their place of stay are particularly important and play a decisive role in illegal or undocumented migrations.

\subsection{Why People Cross?}

Following are the main reasons why people cross the international border:

- Structural demand in developed states

- Poverty

- Overpopulation

- Family reunification

- Environmental degradation

- Political persecution

- Wars and asylum

\subsection{Why Illegal Route or Unauthorised Migration?}

Understandably, the first and foremost reason from the migrant's point of view is that there is no hassle of securing passports and a plethora of other documents, secondly, the 'illegal' means are perceived more successful compared to going through proper channels as there is no guarantee that after completing all the official requirements, that one will get a permit. Thirdly, a formal channel doesn't allow longer stay to work as it has a stipulated period. Fourthly, through the illegal means of crossing, the chances 
of successful migration and finding jobs in India are higher. Fifthly, with less hassle and payment one can find a place closer to home which is an added advantage. Finally, illegal means of crossing are perceived as easy and cost-effective.

\section{India-Bangladesh Border: Territorial De-construction}

India shares $4096 \mathrm{~km}$ of its land border with Bangladesh. West Bengal $(2217 \mathrm{~km})$, Assam $(262 \mathrm{~km})$, Meghalaya $(443 \mathrm{~km})$, Tripura (856) and Mizoram (318) are the states which share their border with Bangladesh. Interestingly, people on both sides live closer to the border and as the border runs through the jungle, hills, riverine villages, and paddy and jute fields making it trouble-free to cross. Indeed, a substantial portion of the border forms the river line; about $790 \mathrm{~km}$ and thus, river border posts have posed a very complex problem since the shifting river course, frequent floods and erosion alters demarcated borders. In addition, the stretch is heavily populated, and interestingly at many places, the farming is carried out till the last inch of the border.

Till recently, the presence of several enclaves along the IndoBangladesh border created stronger complications (The Hindu, 2015).

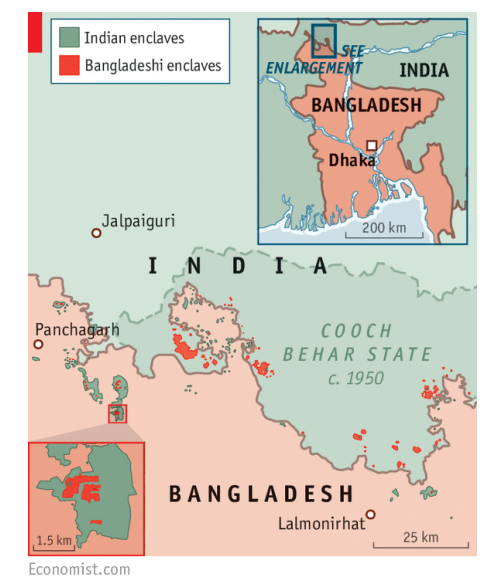

Fig 1. Adapted from The Economist, June 25, 2015 
Also, in some cases the border runs through the middle of several villages, while one section of a house is in one country, another is in the other. For instance, in West Bengal, there are more than 100 villages located right on the zero lines, and in many villages, there are houses where the front door is in India, and the other rear door opens into Bangladesh (Kumar, 2005). This complicates policing Indo-Bangladesh border. The Government of India has taken up the task of wire fencing the entire border and the work is in progress. Meanwhile, Border Security Force (BSF) of India is manning the borderline.

The border was drawn by Sir Cyril Radcliffe, who headed the Bengal Boundary Commission using old district maps as a basis instead of natural barriers such as rivers, etc. in a random way (of demarcating the boundary) in fact, instigated continuous strife between the two countries.

\section{Migration from Bangladesh to India - Continuing Story}

The migration of Bangladeshi nationals into the Indian Territory goes back to undivided India under the British rule. When the British decided to divide India into two countries based on 'twonation' theory in August 1947, the present-day Bangladesh predominant with a Bengali Muslim population became part of Pakistan as 'East Pakistan'. The entire migration issue has its roots in the liberation of Bangladesh in 1971 from Pakistan controlled territory to an independent one. The persecution of Bengali Muslims by the Pakistan army apparently created pandemonium with large scale migration into Indian Territory. While the Indian government sympathised with the fleeing Bangladeshi initially during the 1971 war, New Delhi was more concerned about the increasing migrants to West Bengal and Assam which in fact forced the Indian government to support Bangladesh's pro-independence group in the Bangladesh liberation war. Some estimates reported that around 10 million Bangladeshis had migrated into India during the course of the war and out of which 1.5 million never returned. Of course, a large majority of the refugees were Hindus who later adopted Indian citizenship. 
And thus, the patterns of contemporary migration from Bangladesh go back to colonial times. In addition, people have been mobile in the Bengal delta region for centuries due to flooding, erosion and environment issues. According to the National Population and Housing Census, 2.8 million Bangladeshi household members were living abroad in 2011 (Etzold \& Mallik, 2015) out of which 95 percent of them were men. Out-migration from Bangladesh increased to almost three million between 2005 and 2010. Today, indeed, Bangladesh's economy depends on the emigrants' remittances.

Within India, Assam is most impacted by the illegal migration from Bangladesh. Reportedly, the Muslim population has increased in the border districts of Assam. One estimate holds that not less than one-third of Assam's 22.38 million populations are that of immigrants and their descendants (Hazarika, 2013). Whereas another estimate projects that about 5 million illegal Bangladesh migrants are settled in Assam (Rajeshwar, 1996). Today, given the estimates in the 1990s, there is certainly a reason to believe that the phenomena of migration have gone up and the conservative estimate is that it should be around 6 million. For instance, Myron Weiner's analysis puts Assam's population growth rate at $130 \%$ which is same as the rest of India from 1901 to 1971, means the net population would be 7.6 million in 1971 and, consequently, the share of migrants and their descendants could be at least 7.4 million (Sharma \& Bhushan, 2014). Even if the migration of Hindu population from erstwhile East Pakistan and present-day Bangladesh could be counted, understanding the rate of growth of Muslim population in Assam's southern districts, points to higher growth rates of Muslim population than the all-India aggregates and this phenomenon is attributed to illegal immigration from Bangladesh (see the table below) (Gohain, n.d). 
Table I: The growth rate of population of Muslims vis-a-vis other religious communities from 1971-2001

\begin{tabular}{llllllllll}
\hline $\begin{array}{l}\text { 413 } \\
\text { 3.04 njm }\end{array}$ & \multicolumn{2}{l}{ Total Population } & \multicolumn{5}{c}{$\begin{array}{l}\text { Percentage } \\
\text { population }\end{array}$} \\
\cline { 2 - 10 } & 1971 & 1991 & 2001 & 1971 & 1991 & 2001 & to $71-91$ & $\begin{array}{l}\text { '91- } \\
\end{array}$ \\
\cline { 2 - 10 } & & & & & & & & 2001 \\
Hindu & $10,604,618$ & $15,047,293$ & $17,296,455$ & 72.51 & 67.13 & 64.89 & 41.89 & 14.94 \\
Muslim & $3,592,124$ & $6,373,204$ & $8,240,611$ & 24.56 & 18.43 & 30.92 & 77.42 & 29.30 \\
Christian & 381,010 & 744,367 & 986,589 & 2.61 & 3.32 & 3.70 & 95.37 & 32.54 \\
Others & 47,400 & 247,458 & 97,505 & 0.32 & 1.12 & 0.36 & 426.28 & -60.91 \\
Assam & $14,625,152$ & $22,414,322$ & $26,655,528$ & 100 & 100 & 100 & 53.26 & 18.92 \\
\hline
\end{tabular}

Particularly, out of 27 districts in Assam, Dhubri, Goalpara, Barpeta, Morigaon, Nagaon, Dhemaji, Cachar, Karimganj and Hailakandi are reportedly facing intense crisis due to illegal migration from Bangladesh (see Table II below). As per the 2011 census report, the decadal growth rate in these districts was between 20-30\% (Assam Population Census Data, 2011).

Table II: Growth of Muslim population in per cent in bordering districts of Assam during 1971-2001 (Gohain, n.d)

\begin{tabular}{lllll}
\hline \multirow{2}{*}{ Districts } & \multicolumn{2}{c}{$1971-1991$} & \multicolumn{2}{c}{ 1991-2001 } \\
\cline { 2 - 5 } Dhubri & \multicolumn{1}{c}{ Hindu } & Muslim & Hindu & Muslim \\
Goalpara & -6.07 & +6.0 & -4.0 & +3.84 \\
Barpeta & -9.4 & +8.6 & -1.68 & +3.61 \\
Karimganj & -4.9 & +7.3 & -.10 & +8.9 \\
Marigaon & -4.85 & +5.0 & -5.5 & +3.1 \\
Nagon & -7.87 & +4.90 & -2.34 & +2.29 \\
\hline
\end{tabular}

The West Bengal that borders with Bangladesh is another state within India that is preferred by the migrants owing to the presence of the same linguistic and cultural environment. Allegedly, over five million Bangladeshi Muslims in West Bengal are illegally residing in the State (The Indian Express, 2016). According to Pushpita Das, between 1951 and 2001, in West Bengal while the growth rate of Hindus was 198.54 percent, the Muslims growth rate was about 310.93 percent (Das, 2016). The growth rate of the Muslim population of West Bengal has been noticed 
comparatively higher on especially in the border areas. For instance, between 1991 and 2001 (Ibid), North 24 Parganas registered a population rise of 22.64 percent, Murshidabad 23.70 percent and Malda 24.77 percent respectively, whereas, between 2001-2011 (Sharma \& Bhashan, 2014) 24 Parganas district registered 30.96 percent, while Murshidabad 21.07 percent, and Malda 21.5 percent respectively in the identical periods. Rampant illegal migration from Bangladesh is pointed as a reason for such disparities.

In Tripura, the local residents, indigenous or native tribes, are said to be turning into a marginal community over a period of time by the inflow of undocumented migrants from Bangladesh. T.V. Rajeshwar, former Governor of West Bengal, was of the view that there could be about 7 million of the illegal or undocumented migrants in West Bengal, 5 million in Assam and 2 million in Bihar (Rajeshwaran, 1996). According to the data submitted by the government to the Supreme Court, a total of 9,91,031 Bangladeshis entered India with valid documents but did not return, between 1972 and 1997 (Bharati, 2006). However, generally, it is acknowledged that there is no reliable data on the exact number of illegal migrants from Bangladesh in India.

\section{Consequences/Implications of Illegal Bangladeshi Migration}

The influx of such a large number of illegal Bangladeshi immigrants, particularly in the bordering states, has proved to be a huge challenge for India with serious implications on its resources and national security. It has substantially contributed to the changing demographic pattern in the bordering areas of the northeastern states of India, where the locals feel overwhelmed by the outsiders. This has adversely affected their way of life and led to simmering tension between the two sides. Also, the illegal influx of Bangladeshi immigrants into India has ramifications for India's own internal security. The following are the major consequences: 


\subsection{Socio-Economic Impact}

The economy of the States in north-eastern India that are bordering Bangladesh is predominantly rooted in products like tea, petroleum and forest produce. Agriculture is the primary means of livelihood for most of the population. Considerable migration through illegal means from Bangladesh translates this into a reduced share of already limited produce. Also, over a period of time,the illegal migrants attempt to acquire or occupy land from locals. This occasionally causes alienation of tribes from their ancestral land leading to conflicts. Although there is some law on paper to prevent alienation of tribal land, it remains largely ineffective in Assam. Thus, the major impact of the influx of Bangladeshi nationals is largely on the demography. Allegedly, huge areas of forest land were said to be encroached upon by the migrants (Saikia, 2017). As a result, it is reported that Assam faced declining percent of forest land from 39\% in 1951-52 to about 30\% in 2015-16 (Das \& Talukdar, 2016).

The migrants who entered through the illegal means into India and particularly, West Bengal and Assam got access to government subsidy programmes including ration items apart from availing education and health care from government schools and clinics. As a result, it impacts the state exchequer, an extra fiscal cost. Also, the influx of illegal migrants has displaced native workers as the immigrants are prepared to take up jobs for lower wages than the natives. This in some places has led to competition and conflict.

\subsection{Environmental Impacts}

With the increasing immigrant population in the border districts of Assam, West Bengal and Tripura, understandably there is a mounting pressure on the requirements of fuelwood, timber and land in the forest areas to meet the demand. Even marginal forest lands are cleared to put it to the plough. Forest resources from which various minor products, including fuelwood, are derived are needed in incremental quantities. This has led to substantial environmental impact in the region. 


\subsection{Political Impacts}

One of the main political fallout of large scale illegal migration from Bangladesh had led to the rise of All Assam Gana Sangram Parishad (AAGSP) and All Assam Student's Union (AASU) and also protests in Assam in the 1970s and 1980s. The illegal migrants who settled in the bordering districts of Assam and West Bengal have successfully enrolled their name in the voter list and acquired voter identity cards. As a result, firstly they become illegal voters; secondly, by this means they acquire citizenship. Even if the initiative like the National Register of Citizens (NRC) (Financial Express, 2018) is intended for the detection of illegal Bangladesh migrants, the success of it is yet to be realised.

Reportedly, Bangladeshi immigrants who enter India and settle down in the bordering districts are playing a key role in the political outcome and allegedly they 'determine' the outcome of polls in about 52 Constituencies out of the 292 Assembly Constituencies in West Bengal (Singh, 2002). Consequently, there is a perception that the political power of the locals is being taken away by the immigrants.

\subsection{Law and Order Crisis - Strategic Paralysis}

The influx of Bangladeshi migrants and resulting local conflicts with the local native tribes has led to severe social strain and consequent law and order problems in states like Assam. The Assam Agitation in the late 1970s is the case in point, particularly, the violence in 1983 when native tribes mass murdered over 1700 Bangladeshi Muslim migrants in Nellie village in the more than two decades old secessionist movements in Assam (Mander, 2012). Similarly, the 2012 violence between Bodos and Muslims, allegedly Bengali-speaking Bangladeshis migrants at Kokrajhar districts (Hazarika, 2014) that resulted in the demand for an independent Bodoland is another case of law and order crisis that state faces as a consequence of illegal migration.

Furthermore, illegal immigration is essentially an issue of violation of the law of land. As a sovereign country, it is the right of the state to regulate who it can legally enter into the country, but when 
someone enters illegally it violates the national law. Lt General S.K Sinha, then governor of Assam, said that the massive influx of illegal Bangladeshi is a "demographic invasion of Assam may result in loss of geo-strategically vital districts of lower Assam. It will be only a matter of time when a demand for their merger with Bangladesh may be made... International Islamic fundamentalism may provide the driving force" (The Hindu, 2001).

In Tripura too, the rise of secessionist outfits like All Tripura Tribal Force (ATTF) and National Liberation Front of Tripura (NLFT) is indirectly connected to the issue of illegal migration of Bangladeshis. Reportedly, of late, even some districts like Cooch Behar, Jalpaiguri and Siliguri of West Bengal have witnessed local social discord between the locals and Bangladeshi settlers.

\subsection{Smuggling and Human Trafficking}

The rampant smuggling activities in the India-Bangladesh border are another consequence of the illegal migration involving Bangladeshis. The illegal transaction of such as rice, beef/meat, saris, humans, and drugs are reported regularly in this porous border. Sometimes, bribes and sexual favours are employed by the middlemen in smuggling and trafficking. Also, the linkage between security force officials at the border and the smugglers across the Indo-Bangladeshi border has also been reported. Of late, trafficking of women and adolescent girls are a major concern as they land up in professions like prostitution in Kolkata, Mumbai and other places in India (India Today, 2017). Lucrative cattle smuggling and trade (The Hindustan Times, 2017) from the Indian side to Bangladesh is another problem that is associated with the presence of illegal migrants in the border areas.

\subsection{Security Threats}

Even though illegal migrants are not directly involved in the terrorist incidents in India, their supportive role as host or courier has been reported. But with the reported rise of radicalization in Bangladesh by the growth of hardliners who subscribe to Wahhabism actually "threatens trouble for the region" and beyond it may have spilled over effect on India's security. Significantly, 
reported augmentation of religious intolerance and local Islamic fundamentalist's links with global Jihad groups in Bangladeshisis a cause of worry for India as the Jamaat-e-Islami of Bangladesh is said to have its links with Islamic groups in Assam. And given the mushroom growth of madrasas in the bordering districts of Assam, West Bengal and some of the north-eastern states are up to some extent attributable to illegal immigration from Bangladesh. The West Bengal Chief Minister Buddhadev Bhattacharya's statement in 2003 that "some madrasas are indulging in unlawful activities" is a case in point (Economic Times, 2016). Another worry and a challenge to India's national and societal security is that some Pakistan based groups' support the radical groups in Bangladesh who in turn provide valuable information using their links with the settled illegal migrants in India.

Pakistan's ISI alleged involvement with fundamentalist Islamic parties in Bangladesh and the existence of a large number of Bangladeshi migrants in the Indian side apparently can be viewed as a boon for the above (Nanjappa, 2012).

\subsection{India's Policy Measures and Actions}

The Government of India has adopted a multipronged approach from time to time to end the issue of illegal migration menace through various policies and actionable measures. For instance, the 1983 Illegal Migrants (determination by tribunals) Act, was enacted to present a provision for screening and examination of the complainant, if any, by a local against another person (who is suspected as an illegal migrant) in a same police station limit by District Tribunals, and for appeal to an Appellate Tribunal.ii Similarly, the Foreigners Act, the Passport (Entry into India) Act, and the Registration of Foreigners Act, etc. were passed for detecting and deporting of unauthorized foreign nationals staying in India. In addition, administrative measures such as orders/instructions from the Ministry of Home Affairs were issued to State/ Union Territories periodically in an effort to identify, detect and deport unauthorised foreign nationals/illegal migrants. 
Furthermore, the successive Indian Governments have engaged Bangladesh diplomatically and through regular annual meetings at the level of Home Secretaries and Joint Working Group (JWG) that includes ministries of Foreign and Home Affairs of both countries to find a solution to the pressing issue including the deportation of the detected illegal migrants.

Following the Assam Accord, the Indian government began fencing along the Indo-Bangladesh border since 1987. According to the Minister of State for Home Affairs, Shri Kiren Rijiju in a written reply to a question in the Rajya Sabha, out of the $3326 \mathrm{~km}$ of sanctioned length of fence along Indo-Bangladesh Border, 2746.44 $\mathrm{km}$ has been completed as of February 2018 (Ministry of Home Affairs, 2018). Besides, India has taken the construction of border roads, Border Out Posts (BOPs), installation of floodlights, Hi-tech surveillance equipment, etc. on war footing.

\section{Conclusion}

Yet, there are still many issues that India is facing in terms of effective border management, such as porous and rugged terrain that makes it difficult to have continuous roads and effective patrolling. Equally, another major challenge that India encounters is that of tracing the 'illegal' unauthorised migrants. As there is a system in place to track them and no documentation is being made of the illegal entry or their presence in any of the bordering areas it is extremely difficult to identify or deport them back even though the government has taken steps in the form of updating National Register of Citizens (NRC) by the Assam Govt. under the supervision of the Supreme Court. The NRC update process too is marred by doubt as many illegal migrants have enrolled their names under one or other government categories as Indian citizens. As a result, it is difficult to estimate the true extent of the presence of illegal migrants in the absence of accurate and reliable data. Finally, the negative attitude and non-cooperative approach of Bangladesh on the illegal migration makes it difficult for the Indian government to address the menace effectively. Indeed, it is 
reported that the successive Bangladesh governments have categorically been denying the very existence of the problem.

\section{References}

Assam Population Census Data 2011. (2011). Retrieved from https://www.census2011.co.in/census/state/assam.html

Das, J., \& Talukdar, D. (2016). Socio-economic and political consequence of illegal migration into Assam from Bangladesh. Journal of Tourism $\mathcal{E}$ Hospitality, 5(2). Retrieved from https://www.omicsonline.org/openaccess/socioeconomic-and-political-consequence-of-illegal-migrationinto-assamfrom-bangladesh-2167-0269-

1000202.php?aid $=69610 \&$ view $=$ mobile

Das, P. (2016). Illegal migration from Bangladesh: deportation, border fences and work permits. IDSA Monograph Series, 56, 22. Retrieved from at https:/ / idsa.in/system/files/monograph/monograph56.pdf

Economic Times. (2016, June). Madrasas along Bangladesh border breeding ground of anti-national activities: Dilip Ghosh. Economic Times. Retrieved from https://economictimes.indiatimes.com/ news / politics-and-nation/madrasas-along-bangladesh-borderbreeding-ground-of-anti-national-activities-dilip-ghosh/ articleshow/ 52599049.cms

Etzold, B., \& Mallick, B. (2015). International migration from Bangladesh. Retrieved from http:// www.bpb.de/ gesellschaft/ migration/ laenderprofile/216104/international-migration-from-bangladesh

Financial Express. (2018, January). In-brief: What is Assam's National Register of Citizens updation and how it will impact illegal immigrants. Financial Express. Retrieved from https:// www.financialexpress.com/india-news/explained-in-brief-what-isassams-national-register-of-citizens-updation-and-how-it-will-impactillegal-immigrants/997223/

Gohain, R., Handique, P., \& Borpuzari, A. (2013). Post-1971 illegal immigration from Bangladesh: A demographic changed scenario of Assam. International Journal of Scientific and Research Publications. 3(3), 3. Retrieved from http://www.ijsrp.org/research-paper-0313/ijsrpp1573.pdf

Hazarika, S. (2002). Illegal migration from Bangladesh: problem and long term perspective. Dialogue, A Journal of Astha Bharati, New Delhi, 3(3), 23-32.

Hazarika, S. (2014, May). Complexity and conflict in Assam's 'Bodoland'. Al Jazeera. Retrieved from https:// www.aljazeera.com/ indepth/ 
opinion/2014/05/complexity-conflict-assam-bodola-20145865624188 7 03.html

India Today. (2017, June). Prostitution corridor on Bangladesh border: how human traffickers buy land and smuggle women. India Today. Retrieved from https://www.indiatoday.in/india/story/humantraffickers-fake-documents-india-bangladesh-border-984411-2017-0623

International Organization for Migration. (2010). The future of migration: building capacities for change. World Migration Report. Retrieved from https://publications.iom.int/system/files/pdf/wmr_2010_english.p df

Key Migration Terms. (n.d.). Retrieved from https://www.iom.int/keymigration-terms

Kumar, A. (2005). Bangladesh: fighting over fencing. South Asia Analysis Group(SAAG), 1330. Retrieved from http://www.saag.org/ common/ uploaded_files/paper1330.html.

Mander, H. (2012, August). Assam's tragedy. The Hindu. Retrieved from http://www.thehindu.com/opinion/columns/Harsh_Mander/assa ms-tragedy/article3820732.ece

Ministry of Home Affairs. (2018). Status of fencing work along IndoBangladesh Border. Press Information Bureau.Government of India.Retrieved from http:/ / pib.nic.in/newsite/PrintRelease.aspx?relid=176315

Nanjappa, V. (2012). ISI, DGFI plan to bleed India using Bangladeshi migrants. rediff.com. Retrieved from http://www.rediff.com/ news/ slide-show / slide-show-1-how-bangladeshi-migrants-crawl-intoindian-cities/20120907.htm

Rajeshwar, T.V. (1996, February). Migration or invasion. The Hindustan Times.

Saikia, A. A. (2017). Illegal Bangladeshi immigration into Assam: conflict in political context. IOSR Journal of Humanities and Social Science, 22(9), 3. Retrieved from http://www.iosrjournals.org/iosr-jhss/ papers/ Vol.\%2022\%20Issue9/Version-4/A2209040106.pdf

Sharma, R., \& Bhushan, A. (2014). Illegal immigration of Bangladeshis into India: national security challenges. CS 04 session of 23rd World Congress of IPSA, 7. Canada.

Singh, P. (2002). Management of India's north-eastern borders. Dialogue, $3(3), 67$.

The Hindu. (2001, March). Census shows drop in Assam population. The Hindu. Retrieved from http:// www.thehindu.com/ 2001/ 03/ 30/ stories/1430203e.htm 
The Hindu. (2015, August). India, Bangladesh swap border enclaves, settle old dispute. The Hindu. Retrieved from http:// www.thehindu.com/ news/national/india-bangladesh-swap-border-enclaves-settle-olddispute/article7488497.ece

The Hindustan Times. (2017, July). Cattle smuggled from India harming economy of Bangladesh: Border guards. The Hindustan Times. Retrieved from https://www.hindustantimes.com/india-news/ cattle-smuggled-from-india-harming-economy-of-bangladesh-borderguards/story-s9xgam0281cBJtsrYUuJVP.html

Writ Petition (Civil) No. 125 of 1998, All Indian Lawyers Forum for Civil Liberties (AILFCL) \& Another Vs. Union of India and Others, Counter Affidavit on behalf of the Respondent No. 3. In B. B. Kumāra, (2006). Illegal migration from Bangladesh. Concept Publishing Company.

\section{Endnotes}

${ }^{\mathrm{i}}$ There has been campaigns to discourage the use of the term 'illegal immigrant,' instead advocated the use of terms such as "undocumented immigrants" or "unauthorized immigrants."

ii But given the time consuming elaborate procedure that is involved identifying illegal migrants was virtually made impossible as burden of proofing one as illegal lies on the state than the accused. 